Discussion Paper No. 13-055

\title{
The Effect of Regulatory Scrutiny Asymmetric Cost Pass-through in Power Wholesale and its End
}

Frieder Mokinski and Nikolas Wölfing

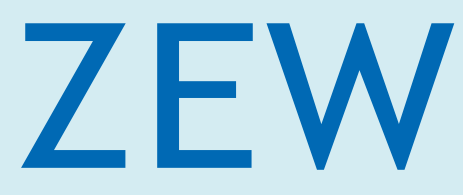

Zentrum für Europäische Wirtschaftsforschung $\mathrm{GmbH}$

Centre for European

Economic Research 
Discussion Paper No. 13-055

\section{The Effect of Regulatory Scrutiny Asymmetric Cost Pass-through in Power Wholesale and its End}

Frieder Mokinski and Nikolas Wölfing

Download this ZEW Discussion Paper from our ftp server:

http://ftp.zew.de/pub/zew-docs/dp/dp13055.pdf

Die Discussion Papers dienen einer möglichst schnellen Verbreitung von neueren Forschungsarbeiten des ZEW. Die Beiträge liegen in alleiniger Verantwortung der Autoren und stellen nicht notwendigerweise die Meinung des ZEW dar.

Discussion Papers are intended to make results of ZEW research promptly available to other economists in order to encourage discussion and suggestions for revisions. The authors are solely responsible for the contents which do not necessarily represent the opinion of the ZEW. 


\section{Non-Technical Summary}

This paper examines the effect of an investigation report by the competition authority on the pass-through of EU emission allowance (EUA) prices to German electricity wholesale prices.

Since January 2005, the European Emissions Trading Scheme (EU ETS) has obligated larger greenhouse gas emitters in the EU to measure their emissions and submit a corresponding amount of allowances by the end of each year. As a result, rising electricity prices could be observed in several European countries. For the German electricity wholesale market, Zachmann and von Hirschhausen (2008) found an asymmetric response to the price for emission allowances: The increase of the electricity price in response to increasing prices on the EUA market was more pronounced than the decrease in response to decreasing EUA prices.

This paper confirms the result of Zachmann and von Hirschhausen (2008) with different data and a more subtle identification strategy, but also limits the time frame for which the asymmetry can be observed. In March 2006, the German competition authority published a paper in order to prepare for a hearing on emissions trading and electricity price formation with a surprisingly critical assessment of the pass-through of EUA prices to electricity prices. The asymmetric pricing pattern, however, was not detected at the time of the report, nor had it been part of the investigations. Nevertheless, our results suggest that the asymmetric pricing pattern disappeared by the time the report was published. By means of the chosen methodology, we can exclude other major events, such as the sharp fall of EUA prices in April 2006, as driving factors for our results. Our findings therefore evidence the deterring effect of regulatory oversight on firms, exhibiting non-competitive pricing behavior on concentrated markets. For recent years, we cannot find any asymmetric pass-through of EUA prices. Several robustness checks support our results. 


\section{Das Wichtigste in Kürze}

Diese Arbeit untersucht die Auswirkung eines Untersuchungsberichts des Bundeskartellamts auf die Weitergabe von EU-Zertifikatspreisen am deutschen Großhandelsmarkt für Strom.

Seit Anfang 2005 verpflichtet das europäische Emissionshandelssystem (EU ETS) größere Verursacher von Treibhausgasen, ihre Emissionen zu erfassen und am Ende jeden Jahres eine entsprechende Anzahl an CO2-Zertifikaten (European Emission Allowances - EUA) vorzulegen. In mehreren europäischen Ländern wurden daraufhin steigende Strompreise beobachtet. Für die deutsche Strombörse fanden Zachmann and von Hirschhausen (2008) eine asymmetrische Reaktion des Strompreises auf Veränderungen des Börsenpreises für $\mathrm{CO}_{2}$-Zertifikate: Die Reaktion auf Preisanstiege im EUA-Markt, so Zachmann and von Hirschhausen (2008), war ausgeprägter als die Reaktion auf Preissenkungen.

Dieses Diskussionspapier bestätigt das zentrale Ergebnis von Zachmann and von Hirschhausen (2008) mit anderen Daten und einer verfeinerten Methodik, schränkt jedoch den Zeitrahmen, in der die Asymmetrie beobachtet werden kann, ein. Im März 2006 veröffentlichte das Bundeskartellamt ein „Sachstandspapier zur Vorbereitung der mündlichen Verhandlung in Sachen Emissionshandel und Strompreisbildung"mit einer überraschend kritischen Bewertung der Preisweitergabe von EUA-Preisen am Strommarkt (BKartA, 2006). Die asymmetrische Preisbildung war zum Zeitpunkt des Berichts noch nicht bekannt und war auch nicht Bestandteil der Untersuchungen. Unsere Ergebnisse legen dennoch nahe, dass die asymmetrische Preisweitergabe mit der Veröffentlichung des Berichts verschwindet. Anhand der gewählten Methodik können wir andere bedeutende Ereignisse, wie den Einbruch der EUA-Preise im April 2006, als treibende Faktoren unserer Ergebnisse ausschließen. Unsere Ergebnisse belegen somit die abschreckende Wirkung der Wettbewerbsaufsicht bei nicht-wettbewerblicher Preisbildung in konzentrierten Märkten. Für aktuellere Jahre können wir keinerlei Asymmetrie in der Preisweitergabe erkennen. Verschiedene Robustheitstests bekräftigen unsere Ergebnisse. 


\title{
The Effect of Regulatory Scrutiny Asymmetric Cost Pass-through in Power Wholesale and its End
}

\author{
Frieder Mokinski \\ ZEW Mannheim and University of Konstanz \\ Nikolas Wölfing* \\ ZEW Mannheim
}

August 2013

\begin{abstract}
We find an asymmetric pass-through of European Emission Allowance (EUA) prices to wholesale electricity prices in Germany and show that this asymmetry has disappeared in response to a report on investigations by the competition authority. The asymmetric pricing pattern, however, was not detected at the time of the report, nor had it been part of the investigations. Our results therefore provide evidence of the deterring effect of regulatory monitoring on firms which exhibit non-competitive pricing behavior. We do not find any asymmetric pass-through of EUA prices in recent years. Several robustness checks support our results.
\end{abstract}

JEL classification:

L4, L94, Q41, Q52

Key words:

asymmetric price adjustment,

regulatory monitoring,

wholesale electricity markets,

emission trading.

\footnotetext{
We are grateful for valuable comments from Anna Créti and the participants of the EAERE annual conference 2013. We thank Anna-Lena Huthmacher for valuable research assistance. Funding was provided from the project "CFI - Climate Change, Financial Markets and Innovation" chaired by Dr. Paschen von Flotow (Sustainable Business Institute - SBI) and supported by the German Ministry for Education and Research. The paper benefited from the discussion with Dr. Paschen von Flotow and Prof. Dr. Dirk Schiereck (Technical University Darmstadt). All remaining errors are those of the authors.

${ }^{*}$ Corresponding author. Email: woelfing@zew.de; address: L7, 1, 68161 Mannheim; phone: +49(0)621-1235-217
} 


\section{Introduction}

This paper studies the effect of regulatory scrutiny on firms' behavior by means of an example from the first years of emissions trading in the European Union. By showing that the pass-through of emission allowance prices to German electricity prices changed significantly in response to a report on the investigations of the competition authority, we provide direct evidence for the deterring effect of regulatory monitoring.

Since January 2005, the European Emissions Trading Scheme (EU ETS) has obligated the EU's larger greenhouse gas emitters, such as fossil fuel-fired power plants, to measure their emissions and to surrender a corresponding amount of European Emission Allowances (EUA) by the end of each year. Until recently, allowances were distributed across the regulated companies free of charge, but the overall amount of allowances is capped. Companies can trade in the allotted allowances, which are thus given a market price and value. Hence, emission allowances are a necessary and costly input to the electricity production process and electricity wholesale prices in several European countries rose in conjunction with the start of emissions trading in 2005.

Shortly after the introduction of the EU ETS, some energy-intensive industries in Germany called on the competition authority to monitor the price setting of German power producers. According to their line of argument, charging costs for freely allotted allowances constitutes an abuse of market power and should not be allowed. Power producer argued that, in generating an additional unit of electricity they consumed allowances that could otherwise have been sold for profit, irrespective of whether allowances were bought in the market or whether they were part of the initial endowment which they received for free. They claimed to only having factored in opportunity costs, which was general practice in the European electricity market. Since producers did not try to cover that they were factoring in emission allowance prices, they seemed to be convinced that the competition authority would agree with their pricing argument. Nonetheless, the competition authority undertook investigations in the matter and issued hearing summons to RWE and E.ON, two electricity companies which together accounted for more than $60 \%$ of installed capacity in Germany. A progress report (BKartA, 2006) with the interim findings of the investigations was published ten days prior to the hearings in March 2006. It must have come as a surprise to German power producers that the report clearly documented the authority's critical position towards their pricing policy.

Our main point of interest is not whether the competition authority's economic assessment of the situation was correct or not. Instead, we analyze the effect of the authority's communication on the pricing behavior of power producers in the wholesale market for electricity. Our hypothesis is that the authority's assessment, deviating from expectations, led to a structural break in price formation in the German electricity market. Indeed, we demonstrate that the relation between electricity prices and $\mathrm{CO}_{2}$ prices changed in spring 2006. Before the publication of the competition authority's report, emission allowance prices appear to have had an asymmetric effect on the wholesale price for electricity: When EUA prices rose, power prices experienced a sharper increase than the decrease they saw when EUA prices shrank by the same amount. We do not find evidence for an asymmetric pass-through of EUA prices after the publication of the report. Several robustness checks support our findings. Keeping these results in mind and in light of the communication between complainants, defendants and the competition authority, we conclude that electricity providers did change their pricing behavior due to closer monitoring, despite the fact that asymmetries in the passthrough of costs had not yet been discovered at the time and had not been subject of 
the competition authority's proceedings.

Zachmann and von Hirschhausen (2008) (Z\&H in the following) were the first to document an asymmetric reaction of the wholesale price for electricity to fluctuations in EUA prices in 2005 and 2006. The analysis of Z\&H was inspired by the fact that emission allowance prices decreased sharply in 2006, while there was no comparatively strong reaction in power prices. This poses the question in how far the observed pattern might have been an artefact of the drastic change in the EUA-price series. We substantially reinforce their result with a more subtle identification strategy: Due to our choice of data and the specification of our models, our finding of an asymmetric pass-through does not rely on the heavy price movements in the EUA market from April 2006. In addition, we carefully control for outliers in our data to avoid a disproportionately high influence of unusual observations on parameter estimation. Our empirical strategy therefore allows for a robust identification of the asymmetric pricing pattern, whose prevalence is found to be restricted to the time before spring 2006 when the competition authority published its investigation results.

Studies on other European electricity markets confirm a pass-through of emissions allowance prices on power prices. For the first phase of the EU-ETS, Fezzi and Bunn (2009) study day-ahead prices for power in the UK, Fell (2010) studies pass-through on the Scandinavian power market and Kirat and Ahamada (2011) consider power prices for France and Germany. None of these studies, however, takes asymmetric effects into account. The topic has recently enjoyed a renewed interest with more evidence for the second phase of the EU-ETS (Sijm et al., 2012; Fell et al., 2012; Kirat and Ahamada, 2012). Lo Prete and Norman (2013) specifically address the puzzle of an asymmetric pass-through posed by $\mathrm{Z} \& \mathrm{H}$ and show that no such pattern is present in power prices for Germany, France, Belgium, and the Netherlands between 2007 and 2010.

Asymmetric price adjustment has been empirically observed in a number of commodity markets (see e.g. Peltzman, 2000). There is ample evidence especially for the fuel market (Borenstein et al., 1997; Brown and Yücel, 2000, e.g.), that has triggered several contributions to the microeconomic theory of this phenomenon. The theoretical literature studies factors that can induce an asymmetric adjustment of prices such as search costs (Yang and Ye, 2008; Lewis, 2011; Cabral and Fishman, 2012), price adjustment costs (e.g. Kuran, 1983), inventories (Reagan and Weitzman, 1982) or collusion in heterogeneous commodity markets, with private information about demand shocks (Damania and Yang, 1998; Kovenock and Widdows, 1998). However, none of these explanations seems to be applicable to the case at hand, where firms trade a homogeneous product through an exchange-based electronic trading mechanism.

Kolstad and Wolak (2008) (K\&W in the following) study a case which appears to be closely related to ours. Their analysis of the Californian electricity market shows how power generating firms exaggerated emissions permit prices to push up electricity prices in 2000 and 2001. The authors infer "that NOx emissions permits were a convenient vehicle for enhancing the ability of suppliers to exercise unilateral market power in the California electricity market." (Kolstad and Wolak, 2008, p.3). Our case differs from the one of $\mathrm{K} \& \mathrm{~W}$ in two respects: First, the Californian permit market differs from the much broader EU ETS with respect to the potential of a single firm influencing the price for emissions permits. Second, K\&W argue that firms pushed up permit prices to cost-justify higher bids for the marginal plant with the Federal Energy Regulatory Commission. This is in contrast to the deregulated Central-European electricity markets, where there is no regulator who requires firms to cost-justify their bids. The competition authority, however, intervenes when it finds evidence for anti-competitive behavior of firms, and our results witness a change in the pricing pattern when the com- 
petition authority signals that the pass-through of permit prices is under investigation. Despite these differences in the market setting, we take the study of $\mathrm{K} \& \mathrm{~W}$ as evidence that the introduction of emission trading can provide a new instrument for electricity generators to implement anti-competitive strategies.

There is research on the empirical effect of regulatory monitoring on competitive behavior, mainly focusing on the stability of cartels (see e.g. Harrington Jr., 2008, for an overview). McCutcheon (1997) discusses, from a theoretical perspective, to what extent a monitoring competition authority hinders the formation of cartels and thus facilitates collusion. Harrington (2005) analyzes how a cartel would price optimally to prevent suspicions by the competition authority, and in a recent contribution Harrington and Skrzypacz (2011) report on the internal monitoring of cartels when firms have private information about their sales. To the authors' knowledge, however, there is much less evidence on the effect of regulatory scrutiny for anti-competitive conduct when firms are not explicitly engaged in a cartel (see e.g. OFT, 2011).

Our research contributes to the literature in three different aspects. First, we confirm the surprising finding of an asymmetric price adjustment for exchange traded power contracts, and we limit the time frame for which this asymmetry appears in the data, thus putting the result of $\mathrm{Z} \& \mathrm{H}$ into perspective. Second, we confirm that the passthrough of costs has been symmetric in recent years; thus we provide evidence that the price for $\mathrm{CO}_{2}$ emissions from fuel combustion is now adequately reflected in power prices. Third, we closely link the end of the asymmetric cost pass-through to the time when additional information about regulatory monitoring was released to the market. Even though the competition authority was unaware of an asymmetric pass-through at the time, suppliers decided to refrain from this practice when they learned that the regulator was critically assessing their pricing strategies. We interpret our results as evidence for the response of firms to closer regulatory scrutiny, thus adding to the literature on competition monitoring which currently largely focuses on the detection of cartels. Similar to $\mathrm{K} \& \mathrm{~W}$, we thus provide evidence of a potential abuse of emission prices for the implementation of anti-competitive strategies in electricity markets.

The remainder of the paper proceeds as follows. Section 2 briefly describes the communication of the involved parties in the law suit. Section 3 describes our dataset and model specifications. Empirical results are summarized in Section 4. In section 5, we perform various robustness tests. Section 6 concludes.

\section{Complaints, Defendants and Regulatory Communi- cations}

Phase 1 of the European Emissions Trading Scheme began in January 2005. From May to November 2005, the German competition authority registered several complaints about the pricing behavior of German electricity producers. Representatives of energyintensive industries and electricity traders claimed that the large power-producing companies abused their market power in order to pass on emissions allowance prices to electricity prices, despite the fact that they received the allowances free of charge. The complainants argued further that the pass-through of opportunity costs for EUA would not be feasible in other industries regulated by the EU ETS, which operate in more competitive downstream markets. Large "windfall profits" of power generators - from charging for freely allotted emissions allowances - would thus be due to imperfect competition in the electricity sector. 
Other industry experts did not agree with this argument and saw little chance of a regulatory intervention by the competition authority. The association of the German chemical industry (Verband der Chemischen Industrie, VCI), one of the energyintensive industries in Germany with the highest turnover, therefore desisted from joining the complainants according to a representative. ${ }^{1}$

RWE and E.ON, the two power companies which were the main subjects of the complaints, openly defended the price-in of consumed emissions allowances into their sales of electric power, emphasizing that EUA prices are part of their variable costs. The firms argued that the pass-through of these costs evidences marginal cost-based pricing, is thus a sign of a well-functioning market, and should not be sanctioned by anti-trust law. In a statement to the competition authority, both companies referred to other European electricity markets, which, they claimed, also reflected EUA costs in electricity prices (BKartA, 2006, p.13).

The authority finally undertook own investigations in this matter. Hearings summons were issued on March 9, 2006 for March 30, 2006. Ten days prior to the hearings, the authority published a progress report with the interim findings of the investigations (BKartA, 2006). In its assessment of the general market conditions, the report states that RWE and E.ON form a market-dominating oligopoly, and argues that actual emissions trading costs to the generators are far below the opportunity costs which are reflected in the electricity wholesale prices (BKartA, 2006, p. 27). The competition authority therefore concludes that the power producers have a substantial margin which they could use for discretionary pricing. A corresponding finding of the investigations is that Deutsche Bahn AG, the largest domestic electricity consumer, had closed electricity supply contracts, where actual costs for EUA were recompensed, but an appraisal of opportunity costs was explicitly excluded (BKartA, 2006, p.49). The report moreover cites a sector analysis from the European Commission, which laments the generally strong concentration of generators in European electricity markets. In its legal assessment, the authority therefore rejects the most important argument of RWE and E.ON that other European power markets provide a relevant case for comparison. Instead, it proposes to take industries as a benchmark which have been equally affected by emissions trading, and concludes that "... passing on costs of emission allowances is impossible in all other affected sectors because of their competitive settings" (BKartA, 2006, p.51).

To summarize, while the competition authority generally agreed that a pass-through of opportunity costs is in line with the competitive behavior of firms, several key arguments of the complainants were supported in the report. The authority expressed doubts about the scope to which a pass-through is acceptable in the case at hand, and thus concluded that the exact pass-through of emission allowances should be subject to closer inspection (see BKartA, 2006, Section II.3, pp.52-53).

\section{Data Selection and Model Specification}

The following paragraphs sketch the methodology and the data which we use to examine whether the surprisingly bold statement of the competition authority led to a change in the pricing behavior of power producers.

\footnotetext{
${ }^{1}$ Personal interview from May 16, 2012, with Jörg Rothermel, division manager Energy, Climate Protection and Resources, Verband der Chemischen Industrie e.V., Frankfurt.
} 


\subsection{Data Selection}

In our analysis we build upon data for futures contracts with delivery in 2008 or later. The electricity price is measured by a futures contract for base load electricity in Germany that was traded on the European Energy Exchange (EEX) from March 2005 until the end of 2007 (Phelix Baseload Year Futures Cal-08). A corresponding contract for peak load electricity is used for a robustness check (see Section 5). Both contracts specify the whole of 2008 as their delivery period. We measure the price of natural gas by a future for annual base load natural gas delivery that was traded on the Dutch Title Transfer Facility (TTF) (ENDEX TTF Gas Cal-08), which is an important trading venue for natural gas in central Western Europe and is crucial in setting prices for deliveries in Germany ${ }^{2}$. Both time series are depicted in Figure 1. The price of emissions allowances is measured by a futures contract with delivery in December 2008 that was traded on ICE Futures Europe (ICE ECX EUA Year Future Dec-08).

Our choice of data differs in several respects from $Z \& H$, who use electricity futures with delivery in the year 2007 and spot market prices for EUA and gas. Fezzi and Bunn (2009), Fell (2010) and Kirat and Ahamada (2011), in contrast, base their analyses on electricity prices from the spot market. The following paragraphs explain our choice of data.

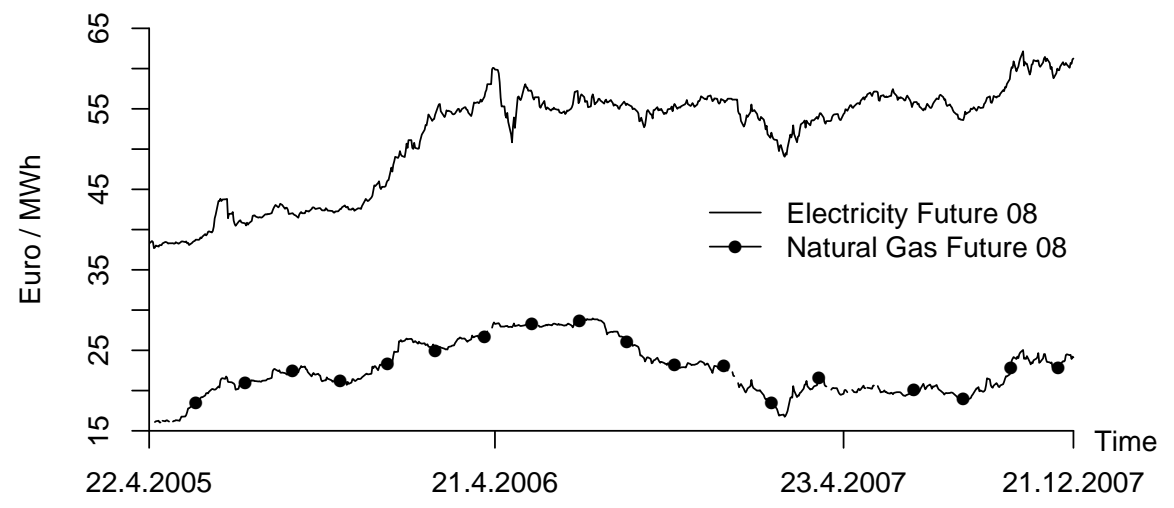

Figure 1: Price data from energy futures contracts with delivery in 2008. Trading period: $2005-2007$

First of all, our analysis benefits from the use of futures contracts, because many short-term factors that cause notable fluctuations of spot prices are irrelevant for the pricing of futures. One example is weather: It can have short-term effects on supply and demand in the power market, but it is hardly forecastable in the long term and should thus not have a large impact on the price of a future contract with long time to maturity. The same holds for natural gas prices in spot and futures markets.

Secondly, we favor futures that expire in 2008 over futures that expire in 2007 for two reason. The first is that the 2008 contracts have been traded for a longer period and we thus have more data to estimate our models. The second, and more important, reason is that contrary to the 2007 contracts, the 2008 futures contracts were less affected by the over-allocation shock on the carbon market that occurred in spring 2006. Figure 2 shows that the prices of the two contracts started to differ greatly in 2006: The price

\footnotetext{
${ }^{2}$ EEX price data for natural gas with delivery in Germany has only been available since 2008 and is thus not applicable to our research.
} 


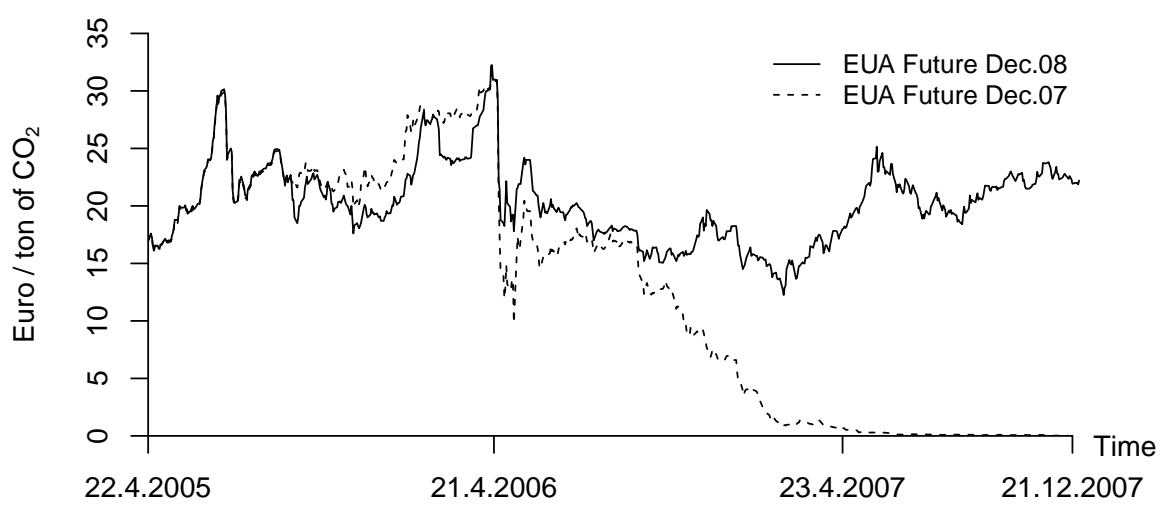

Figure 2: Price data from EUA futures contracts with delivery 2007 vs. 2008. Trading period: $2005-2007$

of EUA futures contracts for December 2007 plummeted beginning in the last week of April 2006, and was ultimately close to zero in 2007 (data: ICE ECX EUA Year Future Dec-07). The massive price decrease documents the market reaction to the news of an over-allocation of EUA in Phase-I of the EU ETS, which ran from early 2005 to late 2007 (see Ellerman et al., 2010, for further information). This over-allocation shock equally affected spot and futures prices for Phase-I-EUA and roughly coincided with the publication of the competition authority's investigation results (March vs. April 2006). It is thus hard to separate the effects of the two events based on EUA prices for Phase-I in an empirical analysis. Figure 2 also demonstrates that the over-allocation shock had a weaker effect on the price of futures contracts with delivery in 2008 . The shock led to a relatively small price reduction in the short term, and prices stabilized in 2006 (data: ICE ECX EUA Year Future Dec-08). The reason for this modest reaction is that the 2008 futures contract is ascribed to Phase-II of the EU ETS which ran from 2008 to 2012, while the over-allocation shock was restricted to Phase-I. By choosing only futures contracts that mature in 2008 , we thus minimize the impact of the overallocation shock in the first phase of European emissions trading on our estimation results.

Finally, our study differs from that of $\mathrm{Z} \& \mathrm{H}$ regarding data frequency. They use weekly data, whereas we employ daily data. This allows us to avoid problems arising from an aggregation of data along the time series dimension (see inter alia Marcellino, 1999).

\subsection{Model Specification}

Equation 1 depicts our regression model.

$$
\begin{aligned}
\Delta Y_{t}= & \sum_{i=1}^{p} A_{i,+} \times \mathbf{1}_{\left(\Delta \mathrm{EUA}_{t-i} \geq 0\right)} \times \Delta \mathrm{EUA}_{t-i}+\sum_{i=1}^{p} A_{i,-} \times \mathbf{1}_{\left(\Delta \mathrm{EUA}_{t-i}<0\right)} \times \Delta \mathrm{EUA}_{t-i} \\
& +\sum_{i=1}^{p} B_{i} \times \Delta Y_{-\mathrm{EUA}, t-i}+\sum_{j} C_{j} \times D_{j t}+C+\varepsilon_{t}
\end{aligned}
$$

where $Y_{t}=\left(\text { Power }_{t}, \text { EUA }_{t}, \mathrm{Gas}_{t}\right)^{\prime}$ denotes the vector of dependent (endogenous) variables and $\Delta Y_{t}$ is its first difference. $\Delta \mathrm{EUA}_{t-i}$ denotes the first difference of the EUA 
price at date $t-i, \Delta Y_{- \text {EUA }, t-i}$ denotes the first difference of the vector $Y_{- \text {EUA }, t-i}=$ $\left(\text { Power }_{t-i}, \mathrm{Gas}_{t-i}\right)^{\prime}$, and $D_{j t}$ is the value of the $j^{t h}$ outlier dummy variable at date $t$. $\left(A_{i,+}, A_{i,-}, B_{i}\right)_{i=1, \ldots, p}$ are coefficient matrices, $\left(C_{j}\right)_{j=1, \ldots, \# \text { Dummies }}$, and $C$ are coefficient vectors. $\mathbf{1}_{(\cdot)}$ is the indicator function, which equals one when the condition in parentheses is fulfilled, and zero otherwise. $\varepsilon_{t}$ denotes the vector of disturbances. It reflects the variation in the dependent variables, which is not modeled explicitly.

Thus, $\sum_{i=1}^{p} A_{i,+} \times \mathbf{1}_{\left(\Delta \mathrm{EUA}_{t-i} \geq 0\right)} \times \Delta \mathrm{EUA}_{t-i}+\sum_{i=1}^{p} A_{i,-} \times \mathbf{1}_{\left(\Delta \mathrm{EUA}_{t-i}<0\right)} \times \Delta \mathrm{EUA}_{t-i}$ implies that positive EUA price changes on date $t-i$ affect the dependent variables according to $A_{i,+}$, whereas negative EUA price changes affect the dependent variables according to $A_{i,-}$. Put differently, EUA price changes may have an asymmetric impact on the dependent variables.

The model is specified in first differences because we find that the gas price and the electricity price exhibit integration of order one: Using the Augmented Dickey-Fuller Test (Dickey and Fuller, 1979), we cannot reject the null hypothesis of non-stationarity for the electricity price or the gas price, regardless of whether we carry out the test with or without an intercept and with or without an additional linear trend. Contrary to the electricity and the gas price, we reject the null hypothesis of a unit root for the EUA price at the five percent significance level. ${ }^{3}$ The EUA price thus appears to be stationary in the time period analyzed. Models with a co-integration relationship between the three prices do not apply due to the stationarity of EUA prices.

We include outlier dummy variables in the regression equation to avoid a disproportionately high influence of unusual observations on the parameter estimates. To this end, we screen the individual daily data for "outliers" using the Mahalanobis distance from the average observation (see Härdle and Simar, 2007, p.293). Observations are classified as outliers if their Mahalanobis distance to the average is greater than 4.0. A total of 17 out of 675 observations fulfill this criterion. Of the 17 outliers, five are detected in the period until March 20, 2006.

We model the data as a vector autoregressive model to accommodate feedback effects among the variables of interest. To understand how feedback effects make our model more realistic, note for example that in our specification an increase in the EUA price may raise the electricity price as a first-round effect, but as power demand should be inversely related to the power price, as a second-round effect, the price for EUA may decrease since power producers' demand for emission rights decreases. Such secondround effects cannot be accommodated in a single equation model.

Note that our model does not include the price of coal. This is in line with the literature cited above, and reflects the general view that the price setting marginal plant is typically gas fired. Nevertheless, section 5 provides robustness checks with coal prices to account for the important share of coal fired power plants in Germany's power generation. Other technologies are either not present in the German power generation system (e.g. oil) or hardly ever become marginal (e.g. nuclear).

\section{Estimation Results}

\subsection{Model Estimation and Model Diagnostics}

The model parameters are estimated separately on two subsamples of our data, using the OLS approach presented in Lütkepohl (2005, p.70ff). One subsample comprises data up to March 20, 2006 (hereafter 'sample period 1') while the other comprises data

\footnotetext{
${ }^{3}$ The test regression includes an intercept.
} 
from March 21, 2006 forward (hereafter 'sample period 2'). March 20, 2006 marks the publication of the competition authority's critical report on investigation results. A change in the pricing behavior of power producers should thus be visible as a change of parameters in the corresponding equation of our regression model.

We use the Akaike Information Criterion (Lütkepohl, 2005, p.162ff) to determine the number $p$ of lagged price changes considered in the regression model and conclude that $p=1$. Table 1 presents estimation results for both subsamples. Coefficients for outlier dummy variables $\left(C_{j}\right)$ and the regression constant $C$ are not depicted.

The upper panel of Table 1 depicts the estimation results for sample period 1, before the publication of the competition authority's investigation results. The second column depicts coefficients for EUA price increases, the third for EUA price decreases. As expected from $\mathrm{Z} \& \mathrm{H}$, the reaction of electricity prices (first row) to an EUA price increase (second column, coefficient: 0.19 ) is stronger than their reaction to an EUA price decrease (0.00). A Wald test (see Lütkepohl, 2005, p.102ff) confirms the asymmetry. In particular, we find that equality of the two coefficients (0.19 vs. 0.00$)$ can be rejected at the one-percent test level.

The second row of the upper panel shows the coefficients for the equation with EUA prices as the dependent variable. The entries in the second and third column $(0.26$ and $0.16)$ indicate that there has been some persistence in EUA price changes. When the EUA price rose by one Euro on one day, it typically rose by another 0.26 Euro on the next. With a coefficient of 0.16 , negative price changes were somewhat less persistent. All other coefficient values in this row are insignificant. We control for interactions of the gas price with the other variables (third row / third column respectively), but none turns out to be significant.

before March 21, 2006

\begin{tabular}{lcccc}
\hline & $\Delta$ Power $_{t-1}$ & $\Delta$ EUA $_{t-1} \mathbf{1}_{(\cdot \geq 0)}$ & $\Delta$ EUA $_{t-1} \mathbf{1}_{(\cdot<0)}$ & $\Delta \mathrm{Gas}_{t-1}$ \\
\hline$\Delta$ Power $_{t}$ & -0.02 & $0.19^{* * *}$ & 0.00 & -0.02 \\
$\Delta$ EUA $_{t}$ & -0.13 & $0.26^{* * *}$ & $0.16^{* *}$ & -0.06 \\
$\Delta$ Gas $_{t}$ & 0.07 & 0.03 & -0.01 & 0.01 \\
\hline
\end{tabular}

from March 21, 2006

\begin{tabular}{lcccc}
\hline & $\Delta$ Power $_{t-1}$ & $\Delta$ EUA $_{t-1} \mathbf{1}_{(\cdot \geq 0)}$ & $\Delta$ EUA $_{t-1} \mathbf{1}_{(\cdot<0)}$ & $\Delta \mathrm{Gas}_{t-1}$ \\
\hline$\Delta$ Power $_{t}$ & 0.02 & 0.09 & 0.07 & -0.08 \\
$\Delta$ EUA $_{t}$ & 0.02 & 0.07 & 0.08 & -0.03 \\
$\Delta$ Gas $_{t}$ & 0.03 & 0.01 & 0.05 & $0.13^{* * *}$ \\
\hline
\end{tabular}

Table 1: Estimated regression coefficients in the two subsamples. Rows refer to dependent variables of the regression equation, columns to explanatory variables. *, **, and *** denote significance at the 10-percent, 5-percent, and 1-percent significance level, respectively.

The lower panel of Table 1 depicts estimation results for sample period 2, after the competition authority published its report. In contrast to sample period 1 , the coefficients that describe the reaction of the electricity price (first row) to positive or negative EUA price changes (second and third column) are relatively similar (0.09 vs. 0.07). Both are not different from zero at any common test level. Unsurprisingly, the 
Wald test described above does not detect an asymmetric pass-through of EUA price shocks for sample period 2. Besides the asymmetry, the persistence of day-over-day changes in the EUA price also vanishes. The only significant coefficient refers to the autoregressive dynamics in the day-over-day change in the gas price, and implies that there has been some persistence in gas price changes in sample period 2. All other regression coefficients are found to be insignificant. Individually insignificant coefficients, however, do not necessarily imply that there is no significant response to a contemporaneous shock in one of the variables which is working through the system of equations. Subsection 4.2 therefore presents further results from orthogonalized impulse responses.

Finally, we employ a Chow test in order to check whether there is a structural break in the reaction of the electricity price to changes in the EUA prices between sample period 1 and sample period 2 (see Lütkepohl, 2005, p.182ff). Specifically, we test whether the coefficient that refers to the reaction of the electricity price to changes in the EUA price is different between the two sub-samples (Period 1: 0.19 vs. 0.00, Period 2: 0.09 vs. 0.07). We can reject the null hypothesis of no structural break at the ten percent significance level ( $\mathrm{p}$-value of 5.17 percent). We interpret this result as evidence for a break in the pass-through of EUA prices to electricity prices around March 20, 2006. Indeed, we cannot exclude the possibility that firms learned informally somehow earlier about the competition authority's assessment. We therefore performed the same test at every possible break date, which left at least 25 percent of the data points on either side of split. The statistic is completely insignificant for the earliest tested break points. It becomes significant for the first time on February 7, 2006 at the ten percent level. It remains significant at this level from February 16 onwards and becomes significant for the first time at the five percent level on February 21. While the date of March 20 was chosen in light of the observed communication of the competition authority, our tests show that the general insights of the analysis are not sensitive to the choice of this specific date.

The key finding of our analysis can be summarized as follows: electricity producers changed their pricing behavior at around the same time at which the competition authority communicated the result of its investigation. Before, in sample period 1, electricity prices were raised following a rise in EUA prices, but EUA price decreases were not passed on correspondingly. However, there is no evidence for an asymmetric effect of EUA price movements on electricity prices in sample period 2, i.e., after the publication of the competition authorities report in March 2006.

We have performed several model diagnostic checks. In particular, we have employed an ARCH LM Test (Lütkepohl, 2005, p.347ff) and a Portmanteau test (Lütkepohl, 2005, p.345ff) to examine whether regression residuals are serially uncorrelated. The ARCH LM test checks the null hypothesis of no autocorrelation in the residuals until the $h^{\text {th }}$ lag. This test is particularly apt for low values of $h$. For sample period 1, test statistics are insignificant at $h=4$. The Portmanteau Test has the same null hypothesis as the ARCH LM Test, but is better suited for higher values of the parameter $h$. We run a Portmanteau test of autocorrelation in residuals for $h=5$ through $h=30$. Again, we do not find evidence for autocorrelation in residuals for any value of $h$ in sample period 1. For sample period 2, the test statistics of the ARCH LM test exhibit a p-value of 6.93 percent for $h=4$, so there is limited evidence for autocorrelation in residuals. The Portmanteau Test for sample period 2 is weakly significant with a p-value of 7.66 percent at $h=7$. At the remaining horizons, the test statistics are not significant at any common level. Moreover, we have checked whether the model residuals are jointly normally distributed following Lütkepohl (2005, p.174ff). The test clearly 
rejects the null hypothesis of normal distribution for both sample periods. Asymptotic confidence intervals therefore cease to be valid. However, regression coefficients and impulse responses can still be interpreted as usual.

\subsection{Impulse Responses}

In this section we use orthogonalized impulse responses (OIR, see Lütkepohl, 2005, p.56ff) to improve our understanding of how an isolated EUA price change affects electricity prices over time. We check whether EUA price movements only have a short-term asymmetric effect on power prices, or if this effect prevails in the medium and long terms. The OIR approach is used when regression residuals of a vector autoregression model (such as our model in Equation 1) exhibit considerable contemporaneous correlations. With the highest pairwise correlation being .42 in sample period 1 and .60 in the sample period 2, this is definitely the case for the residuals of the VAR model considered above. The OIR approach requires us to establish a causal order between simultaneous shocks. The validity of this ordering cannot be tested by statistical means and has to have the following characteristics: (1) A shock to the first variable in the ordering leads to an immediate reaction in the remaining variables. (2) A shock to the $n^{\text {th }}$ variable in the ordering causes an immediate reaction in all following variables $(n+1, n+2, \ldots)$ (3) A shock to the last variable in the chain does not have an immediate effect on any other variable.

Based on Fezzi and Bunn (2009), we propose the following order for the case at hand: 1. Gas, 2. EUA, 3. Electricity. Gas and EUA are input factors in electric power production and should therefore have immediate effects on power prices. For an ordering of the input factors gas and EUA we refer to Fezzi and Bunn (2009). They propose the above mentioned order based on regression models in which they overcome the endogeneity problem of simultaneous price movements by using an instrumental variable approach.

Figure 3 depicts the cumulated orthogonalized impulse responses of the electricity price to positive and negative EUA price movements for sample period 1 (left panel) and sample period 2 (right panel). The dashed lines represent 90-percent confidence intervals which were estimated using a residual-based bootstrapping method based on 10,000 simulated bootstrap samples (see Lütkepohl, 2005, p.709f). Furthermore, to evaluate whether impulse responses are significantly asymmetric, for each bootstrap sample and horizon the difference between the response to a positive EUA shock and the response to a negative EUA shock has been computed.

Figure 3a shows that a clear asymmetry in the pass-through of EUA prices to electricity prices did exist in sample period 1 . In our bootstrap samples, the difference between the impulse response to a positive EUA price shock and the impulse response to a negative EUA price shock turns out to be positive in more then 99 percent of the simulated cases on each single time horizons (not depicted). It can therefore be concluded that an asymmetric pass-through of EUA prices did take place in sample period 1 , and that it persisted in the long run.

Figure $3 \mathrm{~b}$ depicts the impulse response function of electricity prices in sample period 2. As can be seen, the impulse responses to positive and negative EUA price shocks are very similar. In our bootstrap samples, on each horizon, the number of cases in which the difference between the impulse responses to positive and negative EUA price shocks turns out to be positive is about as large as the number of cases in which it is negative, which confirms that responses were rather symmetric in sample period 2. The impulse responses thus reaffirm the former finding that the asymmet- 


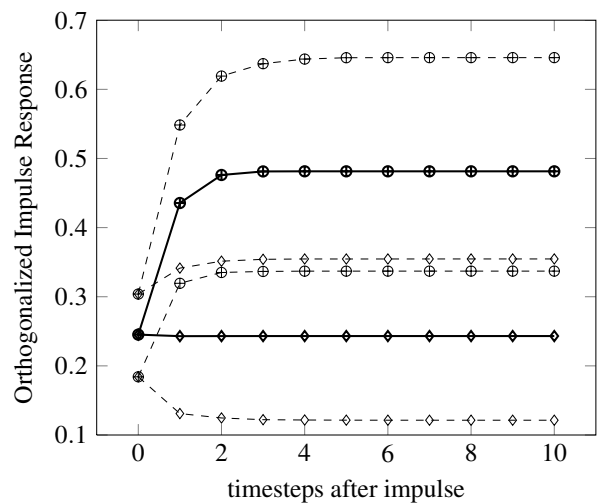

(a)

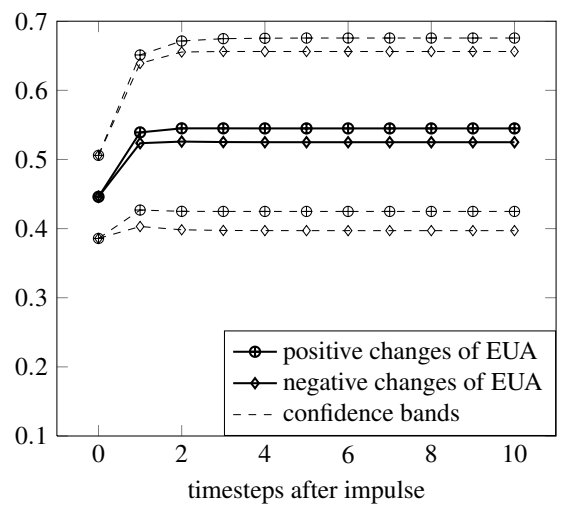

(b)

Figure 3: Impulse response functions for sample period 1 [panel (a)] and sample period 2 [panel (b)]. Solid lines indicate the orthogonalized impulse response of electricity prices to an impulse in EUA prices. $\oplus$ indicates EUA price increase, $\diamond$ indicates EUA price decrease. Dashed lines: corresponding upper and lower bounds of 90 - percent confidence intervals.

ric pass-through stopped around the same time as the publication of the competition authority's report. Another relevant insight can be drawn from Figure 3b: The passthrough of emission allowance costs did not cease. Despite the small and insignificant coefficients for the lagged effect of EUA-price changes on power prices in the second period (see Table 1), the impulse responses do show a significant pass-through in sample period two. This suggests that our model specification in Equation 1 might lack some relevant contemporaneous effects of EUA-prices on power prices. Moreover, both impulse responses in the second period are on a very similar level compared to the impulse response for positive changes of the EUA price in the first period. Thus, one might conclude that the pass-through in the first sample period was incomplete only for decreasing prices.

\section{Robustness Checks}

\subsection{Univariate Analysis}

Our main VAR model in Equation 1 has one decisive drawback: The contemporaneous effect of EUA price changes on electricity prices is not explicitly modeled. While the OIR approach allows us to depict some contemporaneous effects, it imposes a symmetrical relation of electricity prices to input price changes in period 0 . In order to test whether the cost pass-through in period 0 is asymmetrical, we estimate the following univariate regression model:

$$
\begin{aligned}
\Delta \text { Power }_{t}= & b_{1} \Delta \operatorname{EUA}_{t} \mathbf{1}_{\left(\Delta \mathrm{EUA}_{t} \geq 0\right)}+b_{2} \Delta \mathrm{EUA}_{t} \mathbf{1}_{\left(\Delta \mathrm{EUA}_{t}<0\right)}+b_{3} \Delta \mathrm{GAS}_{t} \\
& +b_{4} \Delta \mathrm{EUA}_{t-1} \mathbf{1}_{\left(\Delta \mathrm{EUA}_{t-1} \geq 0\right)}+b_{5} \Delta \mathrm{EUA}_{t-1} \mathbf{1}_{\left(\Delta \mathrm{EUA}_{t-1}<0\right)} \\
& +b_{6} \Delta \mathrm{GAS}_{t-1}+a \Delta \text { Power }_{t-1}+\sum_{i} c_{i} \text { Dummy }_{i t}+c+\varepsilon_{t}
\end{aligned}
$$


This model has the advantage that it depicts asymmetries in the contemporaneous price adjustments (reactions to shocks at the same day). Its drawback is that interactions between the variables cannot be considered. We estimate the model with ordinary least squares. Table 2 presents the estimation results.

\begin{tabular}{lccccccc}
\multicolumn{2}{l}{ before March 21,2006} & \multicolumn{1}{l}{} \\
\hline Coefficent & $b_{1}$ & $b_{2}$ & $b_{3}$ & $a$ & $b_{4}$ & $b_{5}$ & $b_{6}$ \\
Estimate & $0.30^{* * *}$ & $0.19^{* * *}$ & $0.14^{*}$ & 0.00 & $0.09^{*}$ & -0.01 & -0.02 \\
& & & & & & & \\
from March & 21,2006 & & & & & & \\
\hline Coefficient & $b_{1}$ & $b_{2}$ & $b_{3}$ & $a$ & $b_{4}$ & $b_{5}$ & $b_{6}$ \\
Estimate & $0.38^{* * *}$ & $0.5^{* * *}$ & $0.58^{* * *}$ & -0.02 & $0.09^{*}$ & -0.02 & $-0.13^{* *}$
\end{tabular}

Table 2: Univariate regression results for sample period 1 and sample period 2; HAC standard errors (Newey and West, 1987). *,**, and *** denote significance at the 10-percent, 5-percent, and 1-percent significance level, respectively.

We perform a Wald test to check if $b_{1}=b_{2}$ and $b_{4}=b_{5}$ simultaneously, in other words: We test whether the reaction to EUA price movements is asymmetrical. For sample period 1, we obtain a test statistic with a p-value of 2.93 percent. Hence, there is a clear asymmetry. For sample period 2, we cannot reject the hypothesis of symmetry, as expected. Our finding that the pass-through of EUA costs was only asymmetrical prior to authority's investigations can thus be confirmed.

\subsection{Including Coal Prices}

Since coal is a further crucial input factor in electricity production, we add coal prices to our main model from Equation 1. Futures contracts for coal in the German market were not yet publicly traded in 2005 and 2006. We therefore base our data on the HWWI commodity price index for steam coal which refers to coal import prices for the German market. Table 3 displays estimation results for sample periods 1 (upper part) and 2 (lower part).

A striking finding is that the coal price does not seem to be part of the model. The estimated coefficients in all equations are largely unaffected by the introduction of coal prices. The coal price itself does not show any significant relations with the remaining variables in sample period 1, and just a small significant effect of coal on natural gas prices in sample period 2. This is in line with the common belief that the marginal and therefore price-setting plant is typically gas-fired. We therefore conclude that the models we have used throughout this paper are correctly specified and do not suffer from omitted variable biases.

\subsection{Pass-Through for Peak Load Prices}

One might ask if an analysis of the pass-through of EUA costs for peak load electricity yields different results, because demand in peak hours is higher, and the marginal plants, which are then price-setting, are likely to have different average characteristics and possibly a different owner structure compared to the average marginal base load power plants. We therefore reestimated the model in equation 1 , now measuring electricity prices by the corresponding peak load futures contracts, referring to the delivery 
before March 21, 2006

\begin{tabular}{lccccc}
\hline & $\Delta$ Power $_{t-1}$ & $\Delta \mathrm{EUA}_{t-1}^{(\cdot \geq 0)}$ & $\Delta \mathrm{EUA}_{t-1}^{(\cdot<0)}$ & $\Delta \mathrm{Gas}_{t-1}$ & $\Delta$ Coal $_{t-1}$ \\
\hline$\Delta$ Power $_{t}$ & -0.01 & $0.18^{* * *}$ & 0.00 & -0.03 & -0.01 \\
$\Delta$ EUA $_{t}$ & -0.12 & $0.26^{* * *}$ & $0.16^{* *}$ & -0.08 & -0.06 \\
$\Delta$ Gas $_{t}$ & 0.07 & 0.04 & -0.01 & 0.00 & -0.03 \\
$\Delta$ Coal $_{t}$ & 0.04 & 0.01 & 0.09 & 0.20 & -0.03 \\
\hline
\end{tabular}

from March 21, 2006

\begin{tabular}{lccccc}
\hline & $\Delta$ Power $_{t-1}$ & $\Delta \mathrm{EUA}_{t-1}^{(\cdot \geq 0)}$ & $\Delta \mathrm{EUA}_{t-1}^{(\cdot<0)}$ & $\Delta \mathrm{Gas}_{t-1}$ & $\Delta$ Coal $_{t-1}$ \\
\hline$\Delta$ Power $_{t}$ & 0.05 & 0.06 & 0.04 & -0.03 & -0.01 \\
$\Delta$ EUA $_{t}$ & 0.04 & 0.06 & 0.08 & -0.05 & 0.01 \\
$\Delta$ Gas $_{t}$ & 0.03 & 0.01 & 0.04 & $0.14^{* * *}$ & $0.03^{* *}$ \\
$\Delta$ Coal $_{t}$ & -0.04 & 0.00 & -0.06 & 0.12 & -0.02 \\
\hline
\end{tabular}

Table 3: Estimated regression coefficients of the model augmented with coal in the two subsamples. Rows refer to dependent variables of the regression equation, columns to explanatory variables. $* * *$, and $* * *$ denote significance at the 10 -percent, 5-percent, and 1-percent significance level, respectively.

of electric power on weekdays between $8 \mathrm{am}$ to $8 \mathrm{pm}$. Coefficient estimates and the orthogonalized impulse responses can be found in an online appendix to this paper on the journal's webpage.

The results can be summarized as follows: In sample period 1, the asymmetry in the pass-through of EUA price changes is even stronger than for base load prices. In the second sample period, the coefficients that refer to the pass-through of changes in the EUA price become indistinguishable from zero, and their symmetry cannot be rejected. A Chow test strongly supports the hypothesis of a break in the coefficients at the day, when the report of competition authority is published (p-value: 0.017). The results from the impulse response analysis confirm the results. Taken together, all major results from Sections 3 and 4 remain valid or are even reinforced. In addition to the previous results, we now find a small but significant positive response of natural gas prices to lagged changes of the electricity price.

\subsection{Pass-through of EUA Costs in Recent Years}

We also estimate the model in equation 1 with recent data for futures contracts that mature in 2012. Our data ranges from April 2009 to September 1, 2011. Table 4 presents our results. The orthogonalized impulse responses and a graphical description of the time series' can be found in an online appendix on the journal's web page. The coefficients that describe the reaction of the electricity price to positive and negative EUA price shocks are clearly very similar, such that a Wald test finds no evidence of asymmetry. The impulse response functions are in favour of a symmetric pricing pattern as well, a result which is in line with the findings of Lo Prete and Norman (2013). Thus, we come to the conclusion that the asymmetric pass-through of changes in the costs for emission rights has ceased due to the investigations of the German federal competition authority in 2006 and it has not reappeared since. 
from April 1, 2009 to September 1, 2011

\begin{tabular}{lcccc}
\hline & $\Delta$ Power $_{t-1}$ & $\Delta$ EUA $_{t-1} \mathbf{1}_{(\cdot \geq 0)}$ & $\Delta$ EUA $_{t-1} \mathbf{1}_{(\cdot<0)}$ & $\Delta \mathrm{Gas}_{t-1}$ \\
\hline$\Delta$ Power $_{t}$ & -0.05 & $0.25^{* * *}$ & $0.29^{* * *}$ & 0.11 \\
$\Delta$ EUA $_{t}$ & 0.00 & -0.04 & -0.03 & $-0.13^{* *}$ \\
$\Delta$ Gas $_{t}$ & -0.01 & $0.13^{* *}$ & 0.09 & $0.11^{* *}$ \\
\hline
\end{tabular}

Table 4: Estimated regression coefficients in the two subsamples, sample period April 2009 until September 2011. Rows refer to dependent variables of the regression equation, columns to explanatory variables. $*, * *$, and *** denote significance at the 10percent, 5-percent, and 1-percent significance level, respectively.

\section{Conclusion}

Our findings reveal that power prices in Germany reacted much more strongly to increases in the price of emission allowances than to decreases in the year 2005 and in early 2006. This asymmetric pass-through came to an end when the German competition authority pronounced its critical assessment of the price effect of freely allotted emissions allowances on the power wholesale market. Interestingly, the asymmetric pass-through was not detected or discussed before 2007. Our results show that the asymmetric pattern had disappeared about one year earlier. In other words, the competition authority remained ignorant of that aspect almost until the end of its proceedings in the matter.

We interpret our results as a lesson on how regulatory monitoring can change firm behavior. The introduction of emissions trading as a new regulatory instrument appears to have triggered unintended effects. Emissions trading schemes are implemented to internalize external costs of production through a decentralized system. An asymmetric price pass-through of these costs was presumably not the intent of the regulator when the EU ETS was originally set up. The asymmetry vanished, however, when firms received a sufficiently credible signal of closer regulatory scrutiny. We therefore provide direct evidence on how regulatory monitoring can influence the market behavior of the regulated parties, even if the regulator remains unaware of certain practices.

One might question our interpretation for several reasons. First of all, the first phase of the EU ETS was marked by a substantial disruption in the EUA market. Uncertainty about actual emissions in the first year of the EU ETS drove permit prices up to almost 30 Euro per ton of $\mathrm{CO}_{2}$. Information on verified emissions in the year 2005 was released in April 2006. These data witnessed an over-allocation of permits for the covered sectors. Because permits for the years 2005-2007 could not be transferred to later periods, the price of carbon crashed dramatically. It could be possible that this crash influenced the pricing practice in power markets. However, using EUA futures with delivery in 2008, our analysis is based on permit prices for the second period, which did not experience a similar crash and stabilized over the subsequent years. We are thus confident that we can largely exclude the possibility that our results are driven by the turmoil in the first phase EUA market.

Another objection to our interpretation could be that the asymmetry reflects the firms' learning process over time on how to calculate and price in the opportunity costs for emissions allowances. This point can hardly be evaluated empirically because little is known about the firms' individual strategies and their way of institutional learning. 
Given the structure of the German power market, however, it seems unlikely that the relevant companies needed more than one year to learn how to account for emissions allowance prices in their pricing strategy. Four major companies account for about 80 percent of power plant capacity in Germany (RWE, E.ON, Vattenfall, EnBW). Each of these firms employs a professional trading unit, which is monitoring and serving the market continuously. RWE's corporate communication already referred to emissions trading as a future price driver for power markets in 2004 (see e.g. RWE, 2004, slide 11), and in May 2005 informed about RWE's integrated risk management for fuel, carbon and power prices (RWE, 2005). It could thus be assumed that the most relevant firms in the market knew sufficiently well how emissions permit prices relate to their business. Moreover, if learning would have been an issue, we would expect evidence of similar pricing patterns in other sectors or markets. Indeed, it would be interesting to compare our results to the pass-through of EUA prices in power sectors of other European countries. This, however, requires a comparable data set of power futures with a long trading history. Fortunately, such a price history is available for Germany. Unfortunately, even for the UK, with a long history of deregulation, there are no forward prices for electric power earlier than spring 2006. However, there are studies addressing the pass-through of EUA costs in power spot markets e.g. for the UK or Northern Europe. None of these studies reports an asymmetry result. We take this as evidence that the German asymmetry finding was unique in Europe and came to an end in response to a specific German sector inquiry.

One could furthermore question if the date of publication of the competition authority's report really does mark the relevant moment at which the price effect of EUA on power prices changed. The hearing took place on March 30, 2006 and might equally well designate the date at which firms learned about regulatory concerns. However, our results are insensitive to a shift of about ten days for the limiting date between periods. In contrast, we do not expect the firms to have learned earlier about the competition authority's assessment. A significant interference of the authority was not even expected by industry experts of large power consumers. Moreover, our model diagnostic checks do not show any sign of misspecification specifically for the first period until March 20, 2006.

Taken together, we find evidence for a break in the pass-through specifically for emission allowance prices to electricity prices at about the time at which firms learned that the competition authority was monitoring their pricing behavior critically. We can exclude the other main event, the carbon market crash, as a driver of our results, and it seems implausible that firms needed more than a year to learn how to factor in a new input cost. To our knowledge, there is no relevant factor at the time which would alter the relation between EUA and power prices and thus interact with our estimation results. We are therefore confident that we can establish the link between the price pattern in the power futures market and the communication of the competition authority. Better evidence might be obtained from more detailed data on the firms' individual behavior in futures or spot markets. Unfortunately, corresponding data is unlikely to be available for research in the near future. 


\section{References}

BKartA (2006). Bundeskartellamt: Sachstandspapier zur Vorbereitung der mündlichen Verhandlung in Sachen Emissionshandel und Strompreisbildung.

Borenstein, S., Cameron, A., and Gilbert, R. (1997). Do Gasoline Prices Respond Asymmetrically to Crude Oil Price Changes? The Quarterly Journal of Economics, 112(1):305-339.

Brown, S. P. A. and Yücel, M. K. (2000). Gasoline and Crude Oil Prices: Why the Asymmetry? Economic and Financial Review (Federal Reserve Bank of Dallas), Q3:23-29.

Cabral, L. and Fishman, A. (2012). Business as usual: A consumer search theory of sticky prices and asymmetric price adjustment. International Journal of Industrial Organization, 30(4):371 - 376.

Damania, R. and Yang, B. Z. (1998). Price Rigidity and Asymmetric Price Adjustment in a Repeated Oligopoly. Journal of Institutional and Theoretical Economics (JITE), 154(4):pp. 659-679.

Dickey, D. and Fuller, W. (1979). Distribution of the estimators for autoregressive time series with a unit root. Journal of the American Statistical Association, 74(366):427431.

Ellerman, A., Convery, F., De Perthuis, C., and Alberola, E. (2010). Pricing Carbon: The European Union Emissions Trading Scheme. Cambridge University Press.

Fell, H. (2010). EU-ETS and Nordic Electricity: A CVAR Analysis. The Energy Journal, 31(2):1-26.

Fell, H., Vollebergh, H., , and Hintermann, B. (2012). Estimation of Carbon Cost Pass-Through in Electricity Markets. Conference paper, CESifo Area Conference on Energy and Climate Economics.

Fezzi, C. and Bunn, D. (2009). Structural Interactions of European Carbon Trading and Energy Prices. Journal of Energy Markets, 2(4):53-69.

Härdle, W. and Simar, L. (2007). Applied multivariate statistical analysis. Springer Verlag, 2 edition.

Harrington, J. E. (2005). Optimal Cartel Pricing In The Presence Of An Antitrust Authority. International Economic Review, 46(1):145-169.

Harrington, J. E. and Skrzypacz, A. (2011). Private Monitoring and Communication in Cartels: Explaining Recent Collusive Practices. American Economic Review, 101(6):2425-49.

Harrington Jr., J. E. (2008). Detecting Cartels. In Buccirossi, P., editor, Handbook of Antitrust Economics, pages 213-258. MIT Press.

Kirat, D. and Ahamada, I. (2011). The impact of the European Union emission trading scheme on the electricity-generation sector. Energy Economics, 33(5):995-1003. 
Kirat, D. and Ahamada, I. (2012). The impact of phase II of the EU ETS on the electricity-generation sector. Université Paris1 Panthéon-Sorbonne (Post-Print and Working Papers) halshs-00673918, HAL.

Kolstad, J. T. and Wolak, F. A. (2008). Using Environmental Emissions Permit Prices to Raise Electricity Prices: Evidence from the California Electricity Market. available for download at: http://hc.wharton.upenn.edu/jkolstad/kolstad_wolak_aug08.pdf.

Kovenock, D. and Widdows, K. (1998). Price Leadership and Asymmetric Price Rigidity. European Journal of Political Economy, 14(1):167-187.

Kuran, T. (1983). Asymmetric price rigidity and inflationary bias. American Economic Review, 73(3):373-82.

Lewis, M. S. (2011). Asymmetric Price Adjustment and Consumer Search: An Examination of the Retail Gasoline Market. Journal of Economics \& Management Strategy, 20(2):409-449.

Lo Prete, C. and Norman, C. S. (2013). Rockets and feathers in power futures markets? Evidence from the second phase of the EU ETS. Energy Economics, 36(C):312-321.

Lütkepohl, H. (2005). New Introduction to Multiple Time Series Analysis. Springer Verlag, 1 edition.

Marcellino, M. (1999). Some Consequences of Temporal Aggregation in Empirical Analysis. Journal of Business \& Economic Statistics, 17(1):129-136.

McCutcheon, B. (1997). Do Meetings in Smoke-Filled Rooms Facilitate Collusion? Journal of Political Economy, 105(2):330-50.

Newey, W. K. and West, K. D. (1987). A Simple, Positive Semi-Definite, Heteroskedasticity and Autocorrelation Consistent Covariance Matrix. Econometrica, 55(3):703-708.

OFT (2011). The impact of competition interventions on compliance and deterrence. Technical Report oft1391, London Economics on behalf of the Office of Fair Trading.

Peltzman, S. (2000). Prices Rise Faster than They Fall. Journal of Political Economy, 108(3):466-502.

Reagan, P. B. and Weitzman, M. L. (1982). Asymmetries in Price and Quantity Adjustments by the Competitive Firm. Journal of Economic Theory, 27(2):410-420.

RWE (2004). Recent Developments in RWE Trading and the Global Commodity Markets - presentation by Stefan Judisch, Managing Director of RWE Trading GmbH, held at a meeting with investors. accessed online on August 1. 2012.

RWE (2005). Carbon and the Challenge to get the Generation Spread 'to walk on three legs' - presentation by Peter Kreuzberg, Managing Director of RWE Trading $\mathrm{GmbH}$, at a meeting with investors. accessed online on August 1. 2012.

Sijm, J., Chen, Y., and Hobbs, B. F. (2012). The impact of power market structure on $\mathrm{CO}_{2}$ cost pass-through to electricity prices under quantity competition - A theoretical approach. Energy Economics, 34(4):1143-1152. 
Yang, H. and Ye, L. (2008). Search with Learning: Understanding Asymmetric Price Adjustments. The RAND Journal of Economics, 39(2):547-564.

Zachmann, G. and von Hirschhausen, C. (2008). First Evidence of Asymmetric Cost Pass-Through of EU Emissions Allowances: Examining Wholesale Electricity Prices in Germany. Economics Letters, 99(3):465-469. 


\section{A Appendix}

\section{A.1 Peak Load Electricity Futures Prices}

Table $\mathrm{v}$ depicts estimation results for the model in Equation 1, in which base load electricity futures prices are replaced by the corresponding peak load contract. All other procedures are equivalent to the empirical strategy laid out in Sections 3 and 4 in the paper. Figures IV and V present the corresponding orthogonalized impulse responses.

\begin{tabular}{l|ccc}
\hline until 20 March 2006 & $\Delta$ peak load power & $\Delta$ emissions $_{t}$ & $\Delta$ natural gas $_{t}$ \\
$\Delta$ peak load power $_{t-1}$ & 0.04 & -0.06 & $0.09^{* * *}$ \\
$\Delta$ EUA $_{t-1} \mathbf{1}_{(\cdot \geq 0)}$ & $0.25^{* * *}$ & $0.24^{* *}$ & 0.01 \\
$\Delta$ EUA $_{t-1} \mathbf{1}_{(\cdot<0)}$ & -0.01 & $0.14^{*}$ & -0.02 \\
$\Delta$ GAS $_{t-1}$ & 0.01 & -0.07 & -0.01 \\
\hline \multicolumn{4}{|c}{} \\
\hline from 21 March 2006 & speak load power & $\Delta$ emissions $_{t}$ & $\Delta$ natural gas $_{t}$ \\
$\Delta$ peak load power $_{t-1}$ & $0.10^{*}$ & -0.02 & 0.01 \\
$\Delta$ EUA $_{t-1} \mathbf{1}_{(\cdot \geq 0)}$ & -0.00 & 0.10 & 0.03 \\
$\Delta$ EUA $_{t-1} \mathbf{1}_{(\cdot<0)}$ & 0.03 & $0.09^{*}$ & 0.04 \\
$\Delta$ GAS $_{t-1}$ & -0.03 & 0.02 & $0.15^{* * *}$ \\
\hline
\end{tabular}

Table v: Estimated regression coefficients in the two subsamples including peak load electricity prices instead of base load. Columns refer to dependent variables of the regression equation, rows to explanatory variables. $*, * *$, and $* * *$ denote significance at the 10-percent, 5-percent, and 1-percent significance level, respectively. 


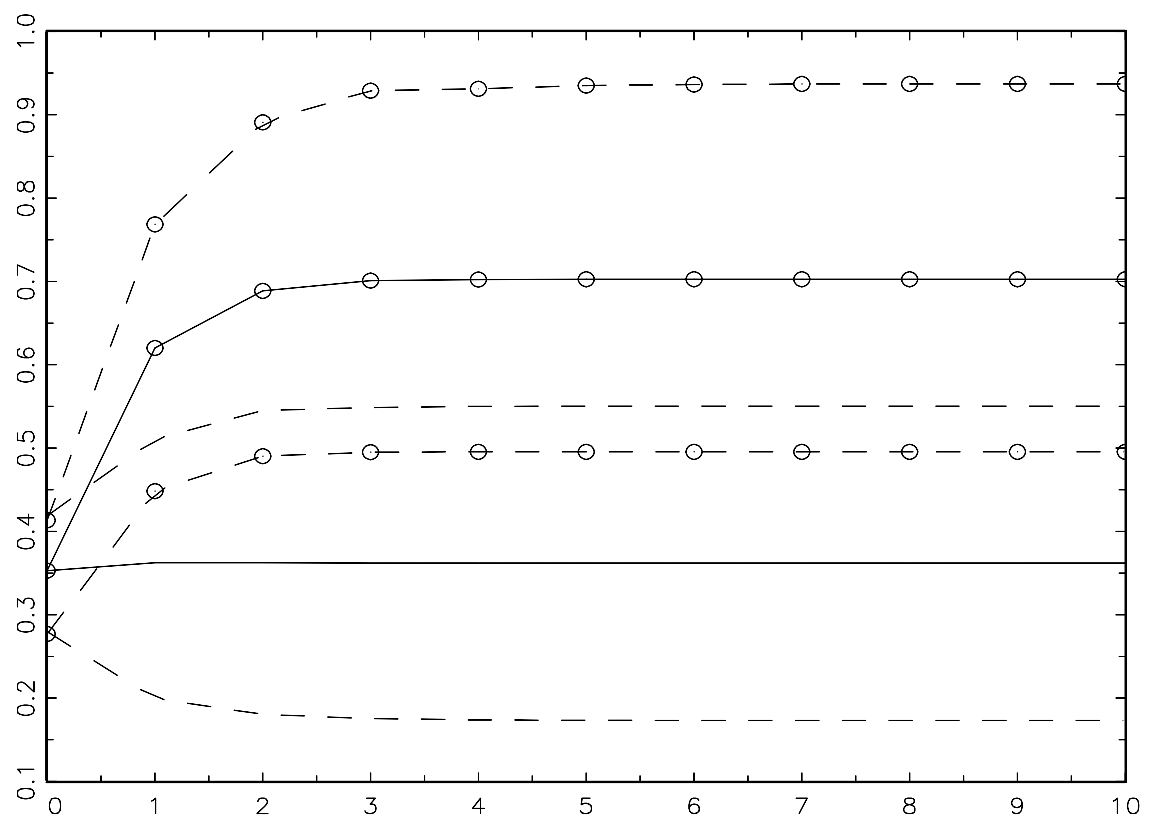

Figure IV: OIR of peakload electricity futures with delivery in 2008 to changes in EUA prices, first sample period; dotted solid line: EUA price increase; solid line: EUA price decrease; analogue dashed line: upper and lower bounds of 90-percent confidence intervals for OIR. 


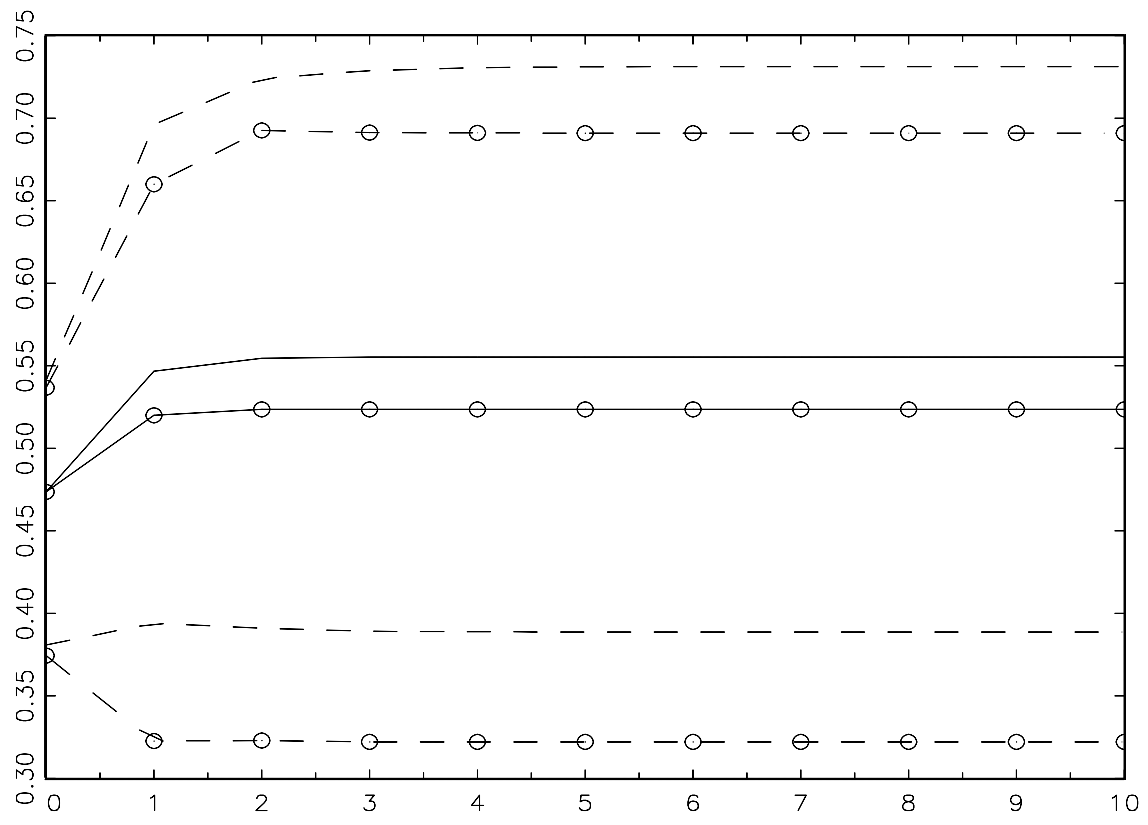

Figure V: OIR of peakload electricity futures with delivery in 2008 to changes in EUA prices, second sample period; dotted solid line: EUA price increase; solid line: EUA price decrease; analogue dashed line: upper and lower bounds of 90-percent confidence intervals for OIR. 


\section{A.2 Pass-Through of EUA Costs in Recent Years}

Figure VI depicts the time series of futures contract prices which were used for the estimation of the coefficients depicted in Table 4 in the paper. Electricity and natural gas prices refer to annual base load delivery over the year 2012 (traded at EEX). EUA prices refer to a futures contract with delivery in December 2012 (traded at ICE London). Figure VII depicts the corresponding orthogonalized impulse response.

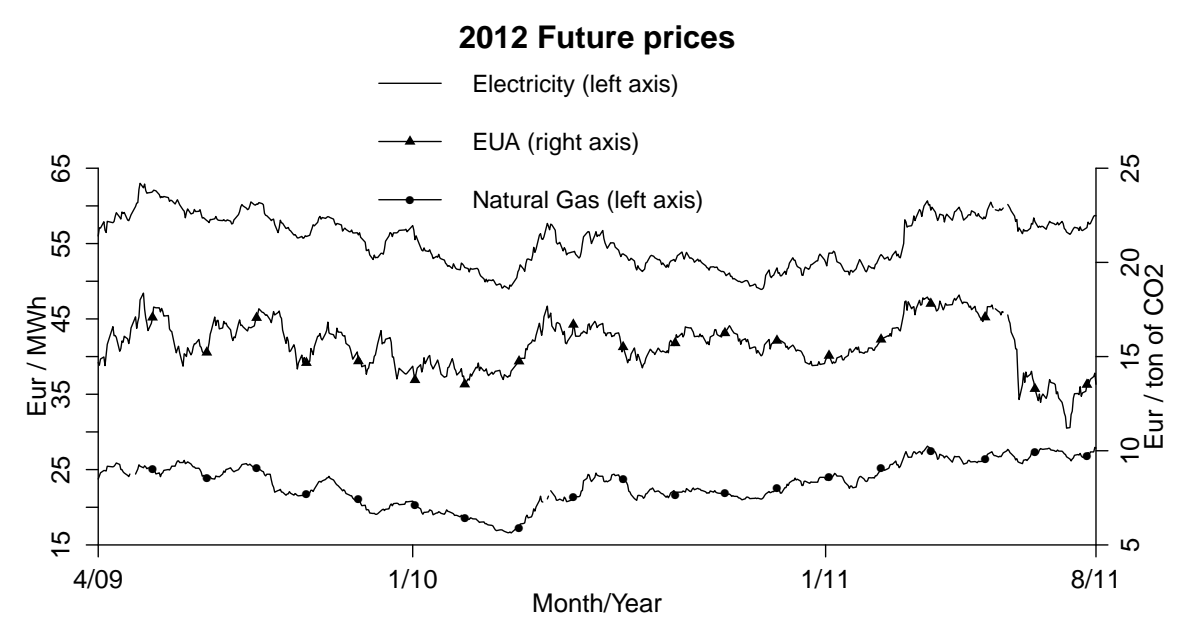

Figure VI: Price time series: futures contracts 2012 


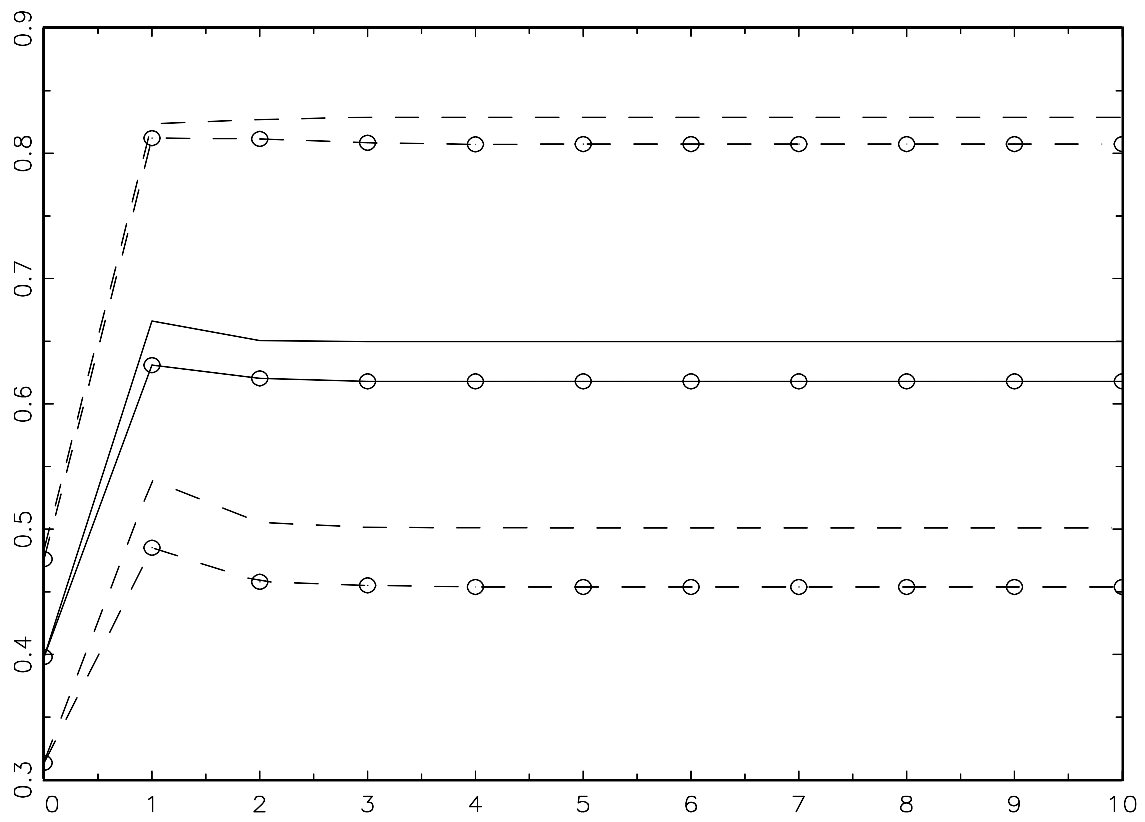

Figure VII: OIR of electricity prices at the current margin; dotted solid line: EUA price increase; solid line: EUA price decrease; analogue dashed line: upper and lower bounds of 90-percent confidence intervals for OIR. 